\title{
Expression of nitric oxide synthase in nasal polyps
}

\author{
Tsuyoshi Yoshimura ${ }^{1 *}$, Tae Chul Moon ${ }^{1}$, Chris St Laurent ${ }^{1}$, Lakshmi Puttagunta ${ }^{2}$, Erin Wright ${ }^{3}$, A Dean Befus $^{1}$ \\ From Canadian Society of Allergy and Clinical Immunology Annual Scientific Meeting 2010 \\ Victoria, Canada. 3-6 November 2010
}

\section{Background}

Nitric oxide $(\mathrm{NO})$ is a short-lived, reactive molecule generated by nitric oxide synthase (NOS). Three isoforms of NOS have been identified including: neuronal NOS (NOS1), endothelial NOS (NOS3) and inducible NOS (NOS2).

\section{Objective}

To identify expression of isoforms of NOS in nasal polyps (NP) and normal nasal tissue, and to determine if differences exist in NOS expression in NP rich in eosinophils (Eo-hi) or with few eosinophils (Eo-low).

\section{Methods}

NP were obtained after endoscopic surgery for chronic rhinosinusitis, and separated into two categories based on eosinophil density. Nasal middle turbinates (MT) were also collected as normal controls from patients who had undergone surgery for pituitary adenomas. To identify cell types expressing isoforms of NOS, double immunostaining was performed using anti-NOS and anti-leukocyte antibodies (e.g. mast cells [MC], eosinophils, $\mathrm{T}$ cells and macrophages).

\section{Results}

Expression of NOS isoforms in all cell types was greater in NP than in MT. Number of NOS2 positive cells in Eo-hi NP was higher than in Eo-low NP. However, there were no differences in the numbers of NOS1 and NOS3 positive cells between Eo-hi and Eo-low NP. Both NOS2 positive $\mathrm{MC}$ and NOS2 positive Eo were significantly greater in NP than in MT. In addition, the percentage of NOS2 positive MC in Eo-hi NP was significantly higher than in Eo-low NP.

\footnotetext{
* Correspondence: yoshimur@ualberta.ca

${ }^{1}$ Pulmonary Research Group, Department of Medicine, University of Alberta, Edmonton, $A B$, Canada

Full list of author information is available at the end of the article
}

\section{Conclusion}

Elevation in NOS2 expression in several cell types might be an important factor in the life history of NP, especially those with an abundance of eosinophils.

\section{Author details \\ ${ }^{1}$ Pulmonary Research Group, Department of Medicine, University of Alberta, Edmonton, $A B$, Canada. ${ }^{2}$ Department of Laboratory Medicine and Pathology, University of Alberta Hospitals, Edmonton, AB, Canada. ${ }^{3}$ Division of \\ Otolaryngology, Head and Neck Surgery, University of Alberta, Edmonton, $A B$, Canada.}

Published: 4 November 2010

doi:10.1186/1710-1492-6-S2-P21

Cite this article as: Yoshimura et al:: Expression of nitric oxide synthase in nasal polyps. Allergy, Asthma \& Clinical Immunology 2010 6(Suppl 2):P21.
Submit your next manuscript to BioMed Central and take full advantage of:

- Convenient online submission

- Thorough peer review

- No space constraints or color figure charges

- Immediate publication on acceptance

- Inclusion in PubMed, CAS, Scopus and Google Scholar

- Research which is freely available for redistribution
( Biolmed Central 